\title{
Crise financeira: o caso japonês
}

\section{Palauras-chave}

Japão, colapsos de bolhas especulativas, crise financeira, política econômica.

Classificação JEL E12, E63, E65

\author{
Key words \\ Japan, collapse of speculative \\ bubbles, financial crisis, \\ economic policy.
}

JEL Classification E12, E63,

\section{Resumo}

Analisar a experiência do Japão, após os colapsos das bolhas especulativas dos ativos e a crise bancária no país, na década de 1990, é o objetivo do presente trabalho. Analisa-se a eficácia das políticas fiscais e monetárias adotadas e discutem-se as medidas tomadas com relação ao setor bancário. A experiência da crise financeira japonesa sugere que a natureza, a velocidade e a ordem em que o poder público implementa medidas podem determinar a magnitude e o custo da crise. Portanto, em retrospectiva, percebe-se que era necessário realizar as seguintes tarefas: 1) recapitalizar o setor bancário; 2) restaurar o crédito; e 3) revigorar a atividade econômica, por meio de medidas fiscais adequadas.
Jefferson Souza Fraga MSc em Economia, FCL/Ar/Unesp; Doutorando em Economia, UFMG

Eduardo Strachman Professor Associado, Depto. Economia, FCL/Ar/Unesp

\section{Abstract}

This paper aims to analyze the experience of Japan after the collapse of speculative bubbles in assets and the banking crisis in the 1990s. An analysis about the effectiveness of fiscal and monetary policy is conducted and the measures taken with respect to the banking sector are also discussed in this paper. The Japanese financial crisis experience suggests that the nature, speed and order in which the government implements measures determine, in large part, the magnitude and cost of the crisis. Therefore, in hindsight, it can be said that the following tasks were necessary: 1) recapitalize the banking sector; 2) restore credit; and 3) reinvigorate the economic activity through appropriate fiscal measures. 


\section{1_Introdução}

Crises financeiras nas economias são como a morte: é certo que ela virá um dia (a nossa e a alheia), mas, sempre que chega, assusta, como se fosse algo totalmente inesperado (Kindleberger, 1992). A correlação entre o que há de desconhecido nas crises financeiras e a morte é o momento e a forma como ocorrem, com as crises sendo, em certo sentido, como acontecimentos (mortes) anunciados(as) (Hermann, 2008).

Para Minsky (1986), em sua teoria da instabilidade financeira, uma depressão pode ser evitada ou atenuada com a atuação do Banco Central como emprestador de última instância e a adoção de políticas fiscais contracíclicas ("Big Government"). As políticas públicas, então, deveriam também ser orientadas no sentido de evitar a destruição de instituições financeiras e empresas industriais. Dado que o capitalismo parece enfrentar problemas em seu funcionamento usual por um lado, entre outros, a tendência a manter níveis de emprego abaixo da plena capacidade produtiva (Keynes, 1936) e, por outro, a tendência a produzir desigualdade na distribuição de renda e riqueza - as políticas públicas deveriam ser orientadas para a resolução desses males. Assim, não há dúvida, ao menos para muitos, quanto à necessidade de interven- ções do Estado, implementando políticas e reformas que reduzam a possibilidade de crises.

Nos últimos trinta anos, a economia japonesa experimentou grande crescimento, no primeiro terço, seguido de uma acentuada "estagnação", nos outros dois terços. $\mathrm{O}$ grande crescimento econômico, estendido até o fim da década de 1980, foi acompanhado por um aumento nos preços das açóes, terras e imóveis, seguido por baixo crescimento, estagnação e declínio nos preços destas mesmas ações, terras e imóveis, resultando na mais baixa taxa de crescimento entre os principais países industrializados, durante esse período, quando antes o contrário era verdadeiro: a mais alta taxa de crescimento do mundo desenvolvido. Dois aspectos foram marcantes nessa crise: a prolongada crise no setor bancário e a baixa taxa de resposta macroeconômica a estímulos, provavelmente insuficientes, de políticas fiscais e monetárias.

A teoria econômica e a história recente japonesa - e mesmo internacional, após a crise que se iniciou em 200708 - sugerem que uma recessão pósbolha especulativa é muito mais difícil de combater do que uma desaceleração conjuntural, e que os efeitos deletérios sobre o crescimento podem ser longos. De fato, grande parte dos problemas da crise 
financeira do Japão não foi resolvida, antes de uma, ou talvez duas, "décadas perdidas". Assim, os eventuais sucessos e fracassos japoneses no combate à crise tendem a ser de interesse também para outras economias, ofertando um rico e variado aprendizado, o qual pode orientar as políticas econômicas no combate às crises financeiras futuras (Kregel, 2009). Este trabalho tem como objetivo responder a estas perguntas: quais os principais fatores que deixaram a economia japonesa virtualmente estagnada, por cerca de duas décadas, com deflação nos preços dos ativos e uma prolongada crise bancária? A política fiscal expansionista foi eficaz e utilizada de forma consistente? A quantitative easing policy ${ }^{1}$ implantada, conjuntamente com a política de taxa nominal quase zero de juros, foi eficaz?

Para tanto, este trabalho está dividido em quatro seções, além dessa introdução e das consideraçôes finais. A primeira seção apresenta as principais conseqüên- cias diretas e indiretas do fim do processo especulativo no mercado acionário e imobiliário. A segunda analisa a eficácia da política fiscal adotada na economia japonesa, durante os anos 90. Uma análise em torno da eficácia da política monetária é realizada na terceira seção. A quarta seção discute as medidas tomadas com relação ao setor bancário. Por fim, as consideraçóes finais procuram resumir todas as respostas às questóes levantadas ao longo dessa introdução.

\section{2_Experiência japonesa: fatos estilizados da década perdida}

A apreciação "forçada" do iene, após o Acordo do Plaza de $1985,{ }^{2}$ e a desregulamentação financeira ${ }^{3}$ - tendo ainda, como pano de fundo, o excesso de liquidez da economia japonesa, alimentado pela política monetária expansiva e pela explosáo nos preço dos ativos - em gran-

\footnotetext{
"O termo "quantitative easing" é usado para descrever a política centrada na compra de títulos do governo japonês, por parte do Banco Central Japonês (BOJ).

${ }^{2}$ Em 1985, o relaxamento dos controles das taxas de juros, começou com a liberalização das taxas de depósito a prazo.
}

\author{
${ }^{3}$ A desregulamentação do \\ sistema financeiro japonês \\ na década de 1980 estava \\ inserida no processo de \\ internacionalização da \\ economia japonesa e \\ visava a diversificação dos \\ instrumentos financeiros \\ à disposição do público
}

e a elevação do grau de
concorrência. Foram criadas
diversas formas de captação
de recursos para as empresas,
especialmente no mercado
externo de capital. Nesse novo
período, a liberalização das
transaçóes cambiais permitiu
a emissáo de títulos de dívida
em mercados externos, sem exigências de colaterais, presentes no caso doméstico. Assim, entre 1983 e 1987, a utilização desse recurso para a captação das empresas cresceu substancialmente. 
de medida originaram as bolhas nos preços imobiliários, nos mercados acionários e, posteriormente, a crise bancária dessa economia. Mckinnon e Ohno (1997, caps. 6 e 7) creditam ao Acordo do Plaza o processo especulativo pelo qual passou a economia japonesa. A sobrevalorização do iene causou uma forte pressão deflacionária sobre a economia japonesa, da segunda metade da década de 1980 até meados dos anos 1990, e as políticas monetárias implementadas (queda nos juros, em vez de estímulos fiscais), após o acordo, visavam compensar a perda de dinamismo da economia. Nesse contexto, a política monetária expansionista teria contribuído para um aumento contínuo nos valores dos ativos, principalmente no mercado imobiliário, resultando em uma bolha especulativa. $^{4}$

De forma resumida, pode-se dizer, portanto, que o boom que originou a bolha especulativa na economia japonesa foi gerado e expandido por um complexo de interaçôes de diversos fatores que intensificaram as expectativas otimistas. Interligados entre si, os fatores que são frequentemente apontados como determinantes deste comportamento dos ativos são:

- a desregulamentação do sistema financeiro, na década de 1980;

- o Acordo do Plaza, de 1985;

- a condução da política monetária.
Assim, o mercado acionário japonês, após a elevação extraordinária, em que os preços dos ativos quase triplicaram em apenas quatro anos, despencou em 1990. Os ganhos com a expressiva elevação nos preços dos ativos, durante o período da bolha especulativa, ${ }^{5}$ foram perdidos completamente nos doze anos seguintes, com a maior queda ocorrendo nos dois primeiros anos e meio após o estouro daquela bolha. Em o mercado imobiliário também começou a apresentar problemas, após a triplicação dos preços dos imóveis, entre 1985 e 1990: estes mesmos preços, em 2000, voltaram ao seu nível inicial de meados da década de 1980 (Gráfico 1).

O colapso das bolhas especulativas interrompeu o longo período de crescimento da economia japonesa no pós-guerra, ${ }^{6}$
Estados Unidos, causando conseqüências desastrosas para a economia japonesa.

${ }^{5}$ Para definiçōes de "bolha especulativa", ver Kindleberger et al. (1992), Minsky (1986) e Oreiro, (2001).

${ }^{6}$ Para uma abordagem das causas dos processos especulativos na economia japonesa e um panorama macroeconômico da crise financeira japonesa, ver Ito (2000, 2003), Torres Fo. (1992, 1997, 2000) e Fraga (2011). 


\section{Gráfico 1_Preço de ativos no Japão (1985-2006)}

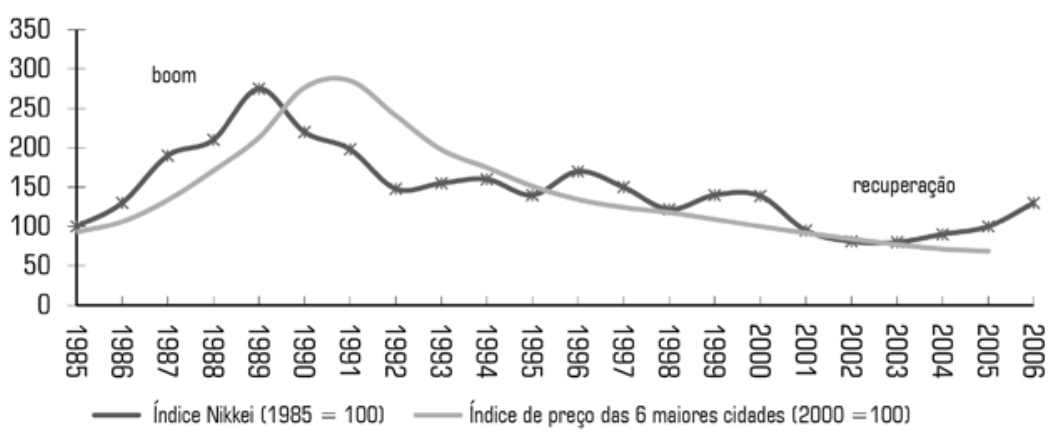

Fonte: Bank of Japan.

com a economia caindo em forte estagnação, mas os efeitos imediatos não foram devastadores. Após apresentar taxa de crescimento próxima a 4\%, no início da década de 1990 (entre 6\% e 8\% ao ano, em 1990 e 1991), a economia estagnou, na segunda

\section{Gráfico 2_Crescimento e desemprego, no Japão (em porcentagem)}

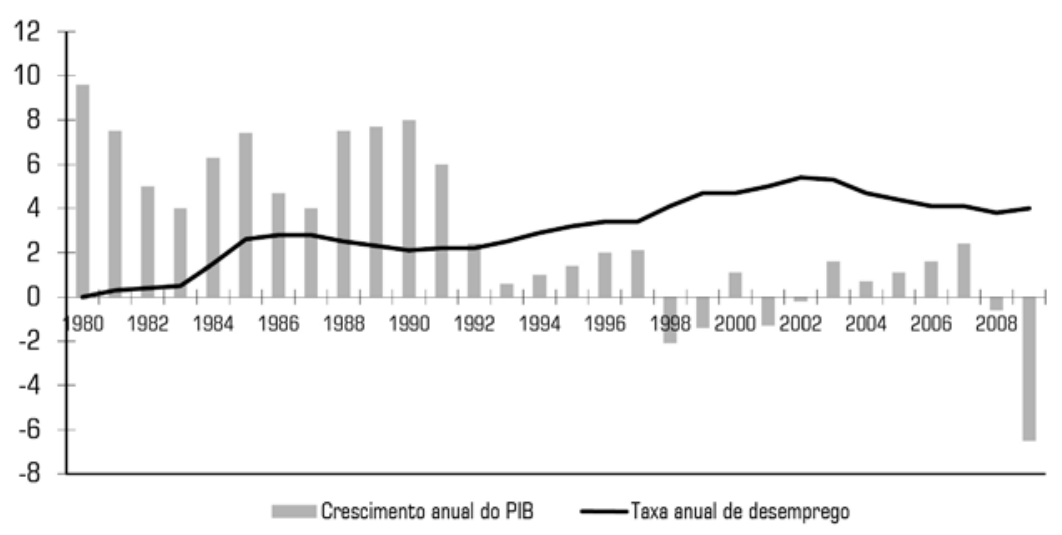

Fontes: FMI, WEO Database. metade da década, com uma média de crescimento próxima a $1 \%$ (Gráfico 2 ).

A taxa de desemprego começou a se ampliar gradualmente, até chegar a níveis elevados para os padróes japoneses, em torno de 5\%, após 2000, e com a taxa de inflação caindo de 3,5\% para praticamente zero, entre 1991 e 1998, e tornando-se negativa, entre 1999 e 2006 - fora os dois anos (2004 e 2006) em que foi nula (International Monetary Fund, 2011). No entanto, a princípio, era esperado que a economia do país respondesse de forma rápida, uma vez que se acreditava que ela passava por uma recessáo cíclica normal, não necessitando de uma política agressiva por parte do governo, dados os sinais de recuperação, entre 1994 e início de 1997, do PIB e da taxa de inflação. A percepção do grave problema pelo qual passava a economia japonesa tornou-se evidente, contudo, quando eclodiu uma crise no setor bancário, em 1997. O colapso dos ativos japoneses deixou o setor bancário diante de grandes problemas com os no-performing loans, aumentando os riscos de mais um longo período de economia fraca.

De forma geral, a crise financeira japonesa pode ser dividida em quatro fases de baixa e uma de recuperação: a primeira, de "desaceleração", entre 1989 e 1996, e os colapsos das bolhas especulati- 
vas. A segunda, de "intensificação e leve recuperação", entre 1997 e 2000, com a crise no setor bancário, em 1997. Posteriormente, houve leve recuperação, entre 1999 e 2000, em grande medida graças à expansão da economia mundial, principalmente a das economias em desenvolvimento, e aos possíveis impactos às políticas de estímulos fiscais, no Japão. No entanto, seguindo a explosão da bolha de valorizaçáo das empresas de tecnologia, nos EUA, no ano 2000, muitas empresas japonesas viram seus lucros deteriorarem, com um setor bancário ainda frágil, assim implicando uma nova fase da crise financeira.

$\mathrm{Na}$ terceira fase, "renovação do estresse sistêmico”, entre 2001 e 2003, a economia basicamente ficou estagnada, em 2001 e 2002, com o hiato de produto aumentando e causando novamente uma deflação, piorando ainda mais as expectativas dos agentes quanto à recuperação. Medidas mais agressivas foram tomadas para lidar com os empréstimos problemáticos e a escassez de investimentos, tais como a redução da taxa de juros e a implantaçáo da política monetária de quantitative easing. Ademais, a nacionalização de grandes bancos ajudou a diminuir o estresse sistêmico. Em contraste com as tentativas anteriores de recuperação, a demanda interna estava aquecida, dada a revitalização do setor bancário, ou de parte dele, e a falência de algumas empresas "zumbis", as quais não tinham condições de cumprir seus acordos financeiros, ou seja, que já estavam antes tecnicamente falidas. ${ }^{7}$

Como resultado, o crescimento sustentado finalmente se tornou realidade, entre 2004 e 2007 - há a "recuperação sustentada”, com taxa média anual de $2 \%$, queda na taxa de desemprego e aumento das exportaçôes, aumento dos empréstimos bancários e fim da quantitative easing policy; condições globais favoráveis, juntamente com o aumento das exportaçóes, beneficiaram a recuperação desse período.

Por fim, a quarta fase, principia com a economia japonesa absorvendo os impactos da chamada crise subprime, nos EUA: um significativo declínio da demanda externa e a forte apreciação da taxa de câmbio do iene atingiram o país em suas exportaçóes. Entre 2008 e 2009, a taxa média de crescimento do PIB nominal caiu para $-4,05 \%$ e $-2,1 \%$ no primeiro trimestre de 2010. Em resposta, o BOJ cortou a taxa de juros para a faixa de $0 \%$ a $0,1 \%$, e o Ministério das Finanças $(\mathrm{MoF})$ atuou no mercado de divisas pela primeira vez, desde 2004, para frear a alta do iene frente ao dólar. Ademais, a Formação Bruta de Capital Fixo (FBCF), que havia atingido, na década de 1980, uma taxa média de $29,52 \%$ do PIB, caiu para uma taxa média de 22,6\% entre, 2002 e 2009 (International Monetary Fund,
${ }^{7}$ Empresas que contribuíam pouco para a produçáo nacional e ainda demandavam empréstimos bancários, aumentando o volume dos no-performing loans. 
2011), com a produção industrial acompanhando as quatro fases descritas.

Na primeira fase, entáo, entre 1990 e 1996, a produção industrial seguiu o colapso da bolha especulativa, declinando a partir de 1991. Com o surgimento da crise bancária, em 1997, veio a segunda fase. A terceira fase deu-se em 2001, impulsionada pela explosão da bolha de tecnologia de 2000. Para alguns autores, ${ }^{8}$ nesta fase foi empregada uma abordagem mais agressiva, a fim de restaurar a saúde financeira do setor bancário, possibilitando uma recuperação entre 2002 e 2006, com taxas de crescimento industrial quase sempre positivas. Por fim, a crise financeira internacional, que teve início em agosto de 2007, afe- tou tanto o lado real da economia japonesa quanto o comportamento da taxa de câmbio. Contudo, somente no fim de 2007 é que a produção industrial japonesa começa a sua trajetória de queda (Gráfico 3).

O que pode ter contribuído para desacelerar o crescimento econômico japonês além dos estouros das bolhas especulativas e da crise bancária? A crise financeira alterou o potencial de crescimento japonês de longo prazo? Afora os fatores já discutidos até aqui, outros podem ter influenciado. Entre eles: a queda na força de trabalho, com as taxas de investimento e da produtividade convergindo para níveis consistentes com os de outras economias avançadas.

\section{Gráfico 3_Produção industrial do Japão (variação percentual)*}

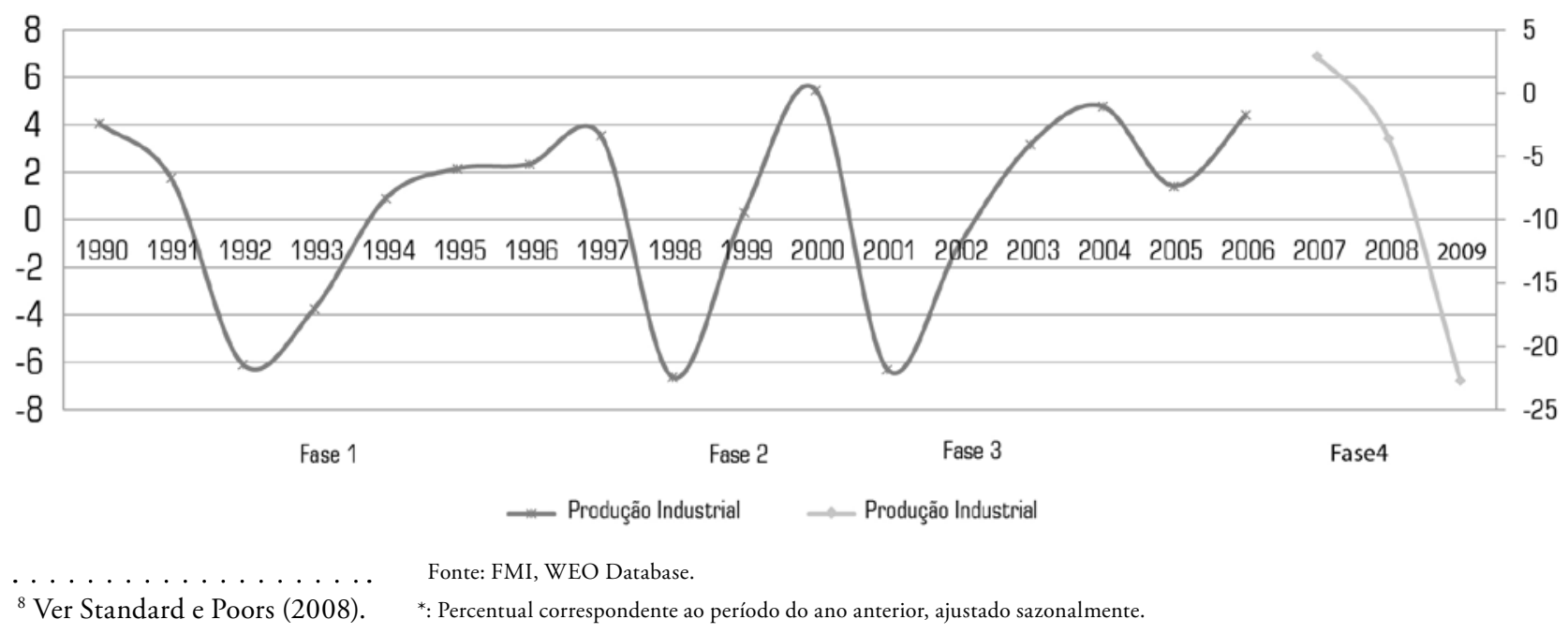


Entre 1955 e 1970, o tamanho da força de trabalho do Japáo cresceu a uma taxa de $1,8 \%$ ao ano, quase duas vezes mais rápida do que o crescimento recente dos EUA (OECD Statextracts). Em 1985, esse valor havia caído para próximo de um terço daquela taxa. A taxa de investimento média da economia japonesa, de $22,7 \%$, entre 2005 e 2009, aproximou-se das taxas do Canadá, França e Itália (22\%, $21 \%$ e $20,54 \%$ ) (International Monetary Fund, 2011). Finalmente, a taxa média de crescimento anual da produtividade do trabalhador japonês apresenta queda consistente entre 1955 e 2009 (Gráfico 4).

A partir de 1994, há um enfraquecimento de todos os indicadores. E, em menor magnitude, a FBKF, sofrendo lento processo de queda, após a crise, ${ }^{9}$ aproximou-se das taxas de outras economias avançadas. Por outro lado, a queda da produtividade foi acentuada. No entanto, postulamos que a crise financeira alterou alguns dos principais fundamentos da economia japonesa, entre eles a relação entre o setor bancário e o empresarial.

\section{Gráfico 4_Economia japonesa (fundamentos enfraquecidos)}

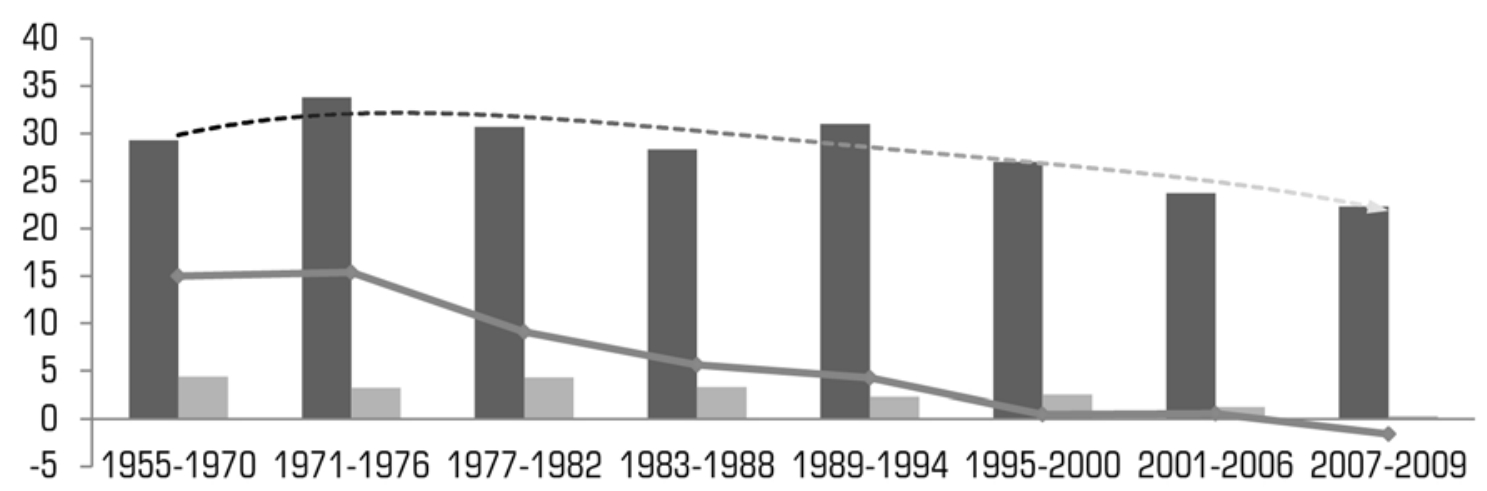

Formação Bruta de Capital Fixo (FBOF, média em \% do PIB)

Produtividade do Trabalho (taxa média de crescimento anual)

$\ldots$ Produto Interno Bruto (taxa média de crescimento anual)

--- Polinômio (Formação Bruta de Capital Fixo (FBOF, média em \% do PIB))

Fontes: FMI, OECD.
9 As taxas de investimento da economia japonesa em relação ao PIB, durante as décadas de 1970, 1980, $1990 \mathrm{e}$ 2000, foram: $33,09 \%, 29,3 \%$, $28,7 \%$ e $23,8 \%$. 


\section{Os estímulos fiscais e sua efetividade na década de 1990}

Os estímulos fiscais adotados pelo governo japonês, durante a década de 1990, encontravam-se sob a forma de orçamentos suplementares, ${ }^{10}$ utilizados para resolver imprevistos. Esses pacotes possuíam valores elevados, totalizando $¥ 184,5$ trilhôes, incluindo garantias de crédito e investimento público. Essas medidas de incentivos tomaram a forma principalmente de investimentos públicos, apoio às pequenas e médias empresas (PMEs), e assistências à manutenção do emprego, no lado das despesas.

Em média, as obras públicas representavam cerca de $40 \%$ das medidas de estímulos fiscais no Japão. Nelas foram incluídos gastos com a construção de estradas e pontes, inclusive em áreas rurais. $\mathrm{Ou}$ tro elemento positivo dos estímulos fiscais foi a expansão das garantias de empréstimos às PMEs. Quando a crise de crédito se tornou evidente, no fim da década de 1990, o governo lançou um programa especial de garantia de crédito, o qual forneceu cobertura de 100\% para os bancos contra perdas. Essas garantias atingiram cerca de $¥ 30$ trilhóes ( $6 \%$ do PIB), em 2001

Contudo, embora essas medidas visassem atenuar a restrição do crédito, também podem ter atrasado a reestruturação necessária, já que havia fortes indícios de que as PMEs que utilizaram este programa estavam mais endividadas e, desta forma, enfrentavam maior risco de default (Matsuura; Hori, 2003). Para Vattipall (2004), um dos principais fatores que provocou o colapso no setor bancário foi o sistema dos Keiretsu. ${ }^{11}$ A relação estreita entre bancos e empresas com alto volume de participação acionária cruzada permitiu às empresas empréstimos bancários e segurança contra aquisiçóes hostis, sendo que esses grandes complexos industriais-
${ }^{10}$ Exemplos típicos desses acontecimentos imprevistos são as catástrofes naturais.

${ }^{11}$ Após 1985, ocorreu um "esgarçamento" dos Keiretsu japoneses (complexo de empresas, trading e financeiras), isto é, uma menor união e sinergia entre as várias empresas, inclusive os bancos, deles constituintes. Isto se deu por causa da abertura financeira, que possibilitou novas formas de captação de recursos, e das dificuldades de algumas empresas do grupo. Sobre esse assunto, ver Gerlach (1989), Levi (1996), Somel (1992) e Torres Fo. (1992). Cabe ressaltar que o estabelecimento de laços entre empresas no Japão não se limitava (ou limita) à forma dos Keiretsu, sendo também usual uma grande variedade de relações inter-empresariais, que guardam maior ou menor proximidade com essa estrutura, normalmente baseadas em esquemas de participação acionária. 
-comerciais-financeiros possuíam enorme influência sobre a política econômica e industrial japonesa. No entanto, os bancos dos keiretsus começaram a sofrer com no-performing loans, em razão dos baixos pagamentos de dividendos e do baixo desempenho de algumas das empresas, que geralmente eram tolerados. Para muitos, esta prática resultou em problemas para a governança corporativa dos bancos japoneses. Afinal, eles emprestavam às empresas do grupo sem avaliação de crédito adequada, porque possuíam capital nessas empresas. E essas empresas tinham pouco incentivo para aderir aos princípios usuais de governança corporativa, porque elas estavam protegidas pela influência política do Keiretsu. Hostile take-overs e combined shareholder action eram raros no Japão, em forte contraste com outros países desenvolvidos.

Em uma interpretação mais otimista, Koo (2009) argumenta que a economia passou por dois estágios que ele denomina de yin (pós-bolha) e yang (normal). Enquanto no estado yang a economia se comporta exatamente como previsto nos modelos neoclássicos, funcionando a política monetária, na fase yin, esta não funciona. Afinal, quando em yin, as empresas estão tentando diminuir suas dívidas, e a forma como fazem isso é através do redirecionamento do fluxo de caixa de investi- mentos para o pagamento de dívidas. Logo, há queda de investimentos, puxando para baixo a atividade econômica. Para o autor, então, a política fiscal pode e deve vir para resgatar e estabilizar a demanda, não importando seu custo.

Os pacotes fiscais do fim da década de 1990, dado o forte aumento do desemprego, direcionaram maior apoio ao emprego e seguridade social, incluindo apoio a idosos. Além disso, em 1999, foram distribuídos vales de créditos, que totalizaram $¥ 0,7$ trilhóes às famílias que potencialmente estavam privadas de liquidez. ${ }^{12}$ Consideráveis cortes fiscais também foram implementados pelo governo japonês, entretanto, com resultados mistos. Em 1994, ocorreram cortes nos impostos de renda, no valor de $¥ 5,5$ trilhóes $(1,1 \%$ do PIB - Tabela 2). No entanto, em 1997, em resposta ao aumento da dívida pública e ao aumento dos custos fiscais de uma sociedade que também passava por um processo de envelhecimento acelerado, o governo mudou o rumo da política e alterou os impostos sobre o consumo, de $3 \%$ para $5 \%$, retirando a temporária reduçáo nos impostos implementada anteriormente e elevando a carga tributária no valor de $¥ 7$ trilhôes ( $1,4 \%$ do PIB).

Contudo, saliente-se que a demanda havia respondido de forma positiva aos cortes nos impostos, até a política com-

\footnotetext{
${ }^{12}$ Kang et al. (2009a) argumentam que a impossibilidade de verificar a renda das famílias forçou o governo a procurar proxies, tais como a presença de crianças ou idosos.
} 
Tabela 1_Cortes de impostos e taxa de crescimento do PIB (década 90)

\begin{tabular}{|c|c|c|c|c|}
\hline \multicolumn{4}{|c|}{ Imposto de Renda (em trilhões de ienes) } & \multirow{2}{*}{$\begin{array}{l}\text { Taxa de crescimento em \% } \\
\text { PIB (per capita) }\end{array}$} \\
\hline Ano & Permanente & Temporário & Impostos corporativos & \\
\hline 1994 & \multirow{7}{*}{3,5} & 5,5 & \multirow{7}{*}{$\begin{array}{c}\text { Permanente } \\
\qquad 2,0\end{array}$} & 0,56 \\
\hline 1995 & & 2,0 & & 1,68 \\
\hline 1996 & & 2,0 & & 3,26 \\
\hline 1997 & & & & 1,41 \\
\hline 1998 & & 4,0 & & $-1,55$ \\
\hline 1999 & & 4,0 & & $-0,51$ \\
\hline 2000 & & $\downarrow$ & & 2,15 \\
\hline
\end{tabular}

Fonte: Ministry of Finance; Cabinet Office e Center for International Comparisons (2009).

pensatória de 1997. E, como era de se esperar, de fato, após tal reversão nas políticas, ocorreu uma contração econômica, com a taxa de crescimento passando a ser negativa, em 1998 e $1999 .{ }^{13}$ Como conseqüência, o governo novamente mudou o rumo de sua política fiscal e reintroduziu um corte no imposto de renda de $¥ 4$ trilhóes, em 1998, seguido por um novo corte de $¥ 6$ trilhóes, em 1999, com a redução dos impostos corporativos (Tabela 1). A redução dos gastos do governo faz

\footnotetext{
${ }^{13}$ A grande recessão japonesa
} foi resultado, assim, também de uma série de erros de política macroeconômica e financeira. Assim, em grande parte, evitáveis (Posen, 1998).

\footnotetext{
${ }^{14}$ É o débito consolidado, descontado de disponibilidades de caixa, aplicaçóes financeiras e outros haveres financeiros.
}

mais sentido quando o setor privado está pronto para carregar a economia. O Japão oferece, então, um exemplo claro do que acontece com uma economia quando o aperto fiscal ocorre antes da desalavancagem do setor privado (Koo, 2009).

A partir de 1997, há uma explosão da dívida líquida pública, ${ }^{14}$ com relação ao PIB japonês. De fato, as receitas governamentais permanecem em uma média de $31 \%$ do PIB, enquanto as despesas totais saltam de $30 \%$, no início da década, para próximas a 38\% do PIB, no ano 2000. Os estímulos fiscais adotados pelo governo japonês durante a década de 1990, e o envelhecimento da sociedade japonesa, representando maior gasto com a seguridade social, em grande medida, explicam essa explosão. Com o aumento dos gastos go- 
Tabela 2_Pacotes de estímulos fiscais e orçamentos suplementares (década de 1990)

\begin{tabular}{|c|c|c|c|c|c|c|c|c|c|c|c|c|}
\hline Ano & & 91 & 92 & 93 & 94 & 95 & 96 & 97 & 98 & 99 & 00 & Total \\
\hline \multirow{2}{*}{$\begin{array}{l}\text { Estímulos } \\
\text { Fiscais }\end{array}$} & No. & 0 & 1 & 2 & 1 & 2 & 0 & 2 & 1 & 1 & 0 & 10 \\
\hline & $\begin{array}{r}¥ \\
\text { Trilhōes }\end{array}$ & 0 & 10,7 & 19,2 & 15,3 & 21,2 & 0 & 40,6 & 24,5 & 14,9 & 0 & 146,4 \\
\hline \multirow{2}{*}{$\begin{array}{l}\text { Orçamentos } \\
\text { Suplementares }\end{array}$} & No. & 1 & 1 & 3 & 2 & 3 & 1 & 3 & 2 & 1 & 1 & 18 \\
\hline & Trilhôes & 0,3 & $-0,7$ & 5,1 & 0,4 & 7,1 & 1,1 & 10,3 & 7,2 & 4,8 & 2,7 & 38,1 \\
\hline
\end{tabular}

Fonte: Cabinet Office, Ministry of Finance.

vernamentais, um déficit médio de mais de 5\% do PIB foi criado, entre 1993 e $2000 .{ }^{15}$ Historicamente, a dívida pública japonesa tem tido um financiamento bastante suave, com taxas de juros muito reduzidas. O grande volume de poupança doméstica e a base de investidores institucionais têm sido estáveis, contribuindo para manter constantes os rendimentos dos títulos do governo japonês, apesar do aumento dessa dívida. Ademais, como vimos, nos últimos anos, o BOJ tem reduzido ainda mais suas taxas de juros, o que fez com que caísse o custo financeiro de rolagem da dívida pública japonesa. ${ }^{16}$

Os primeiros estímulos fiscais foram realizados em 1992, seguidos por pacotes adicionais em toda a década, exceto nos anos de 1996 e 2000. Na Tabela 2, são listados os pacotes e orçamentos suplementares. Como pode ser observado, os estímulos fiscais nestes dez anos perfizeram um total de $¥ 146$ trilhóes. Os dezoito orçamentos suplementares somaram $¥ 38,1$ trilhóes. Apesar dos significativos incentivos fiscais, a economia permaneceu

\footnotetext{
${ }_{15}$ Nesse período, foi observada elevada queda nas receitas ficais japonesas. Este declínio está associado a uma queda na elasticidade fiscal, durante a década de 1990, e ao baixo crescimento e recessão do período (Muhleisen, 2000).
}

\author{
mais rápido do que a sua \\ capacidade de pagá-las, ao \\ menos se mantém estável o \\ peso da carga tributária sobre \\ esta renda. De fato, os déficits \\ do governo japonês na década \\ de 1990 e os excedentes de \\ seguridade social deixaram
}

uma dívida líquida de apenas $15 \%$ do PIB japonês, de longe, o nível mais baixo entre os países do G7 (Posen, 1998). 
${ }_{17}$ Partes da diferença dos estímulos fiscais na década de 1990 surgiram porque os governos locais japoneses se recusaram a gastar em obras públicas, como havia sido solicitado pelo governo nacional (Posen, 1998).

${ }^{18}$ As taxas de crescimento do PIB nominal japonês em 1995, 1996, 1997, 1998 e 1999 foram de $1,4 \%, 2 \%, 2,1 \%,-2,1 \%$ e $-1,4 \%$, respectivamente. estagnada, até o início de 2000. Entre 1993 e 2000, a média de crescimento da economia ficou abaixo de $1 \%$.

Os gastos públicos, como uma porcentagem do PIB nominal japonês, tiveram aumento de 20,9\%, em média, na década de 1980 , para 22,7\%, em média, na década de 1990 (Werner, 2004), isto é, com uma tendência de crescimento positiva, porém com um aumento bastante modesto. A demanda privada contribuiu com aproximadamente $79 \%$, nos anos 80 , e $44 \%$, nos anos 90, para o crescimento do PIB nominal (Cabinet Office).

Enquanto os déficits aparentemente tomaram grandes proporçóes, os impulsos fiscais correlacionados e seus resultados foram modestos, com o "déficit estrutural" aumentando modestamente, entre $1994 \mathrm{e}$ 1998. O déficit estrutural é o déficit que permanece após a correção das variações cíclicas. Por outro lado, o déficit primário - correspondente à diferença entre arrecadação e gastos do governo, sem levar em conta as despesas com os juros da dívida interna pública - sofreu um modesto aumento, até 1998.

O baixo impulso fiscal pode ser reflexo de vários fatores. Entre os mais listados pela literatura, estáo: os investimentos públicos efetivos foram menores que os anunciados, dado que o investimento público inicial do governo central e os or- çamentos suplementares não aumentaram muito, após a segunda metade dos anos 1990, com médias muito próximas entre os dois períodos (Sadahiro, 2005). Os impactos econômicos também podem ter sido limitados pelo grande volume de terras compradas pelo governo, o que tem impacto basicamente nulo sobre a geração de renda, somente com algum resultado sobre o patrimônio dos vendedores dos imóveis e de alguns agentes a eles relacionados (Kalra, 2003). Finalmente, cerca de $15 \%$ dos investimentos públicos não foram efetivamente realizados (Kang et al., 2009a). ${ }^{17}$ Ademais, o limitado impulso fiscal pode ser reflexo da natureza "stop and go" dos estímulos realizados, em particular das prematuras reversóes fiscais. Quando a economia parecia se recuperar, em 1997, o governo começou a reverter os cortes no imposto de renda e a aumentar o imposto sobre o consumo. Ora, quedas nos gastos domésticos acompanharam essas reversóes, levando a economia novamente à recessão. ${ }^{18}$

Compartilhando com os argumentos de Posen (1998), a recuperaçáo poderia ser sustentável, mas foi cancelada por erros de política macroeconômica. O Gráfico 5 divide os componentes do crescimento do PIB nominal japonês durante a pior fase da década perdida. Pode-se ver que um declínio na demanda privada, 


\section{Gráfico 5_Contribuição para o crescimento do PIB no Japão, na década de 1990}

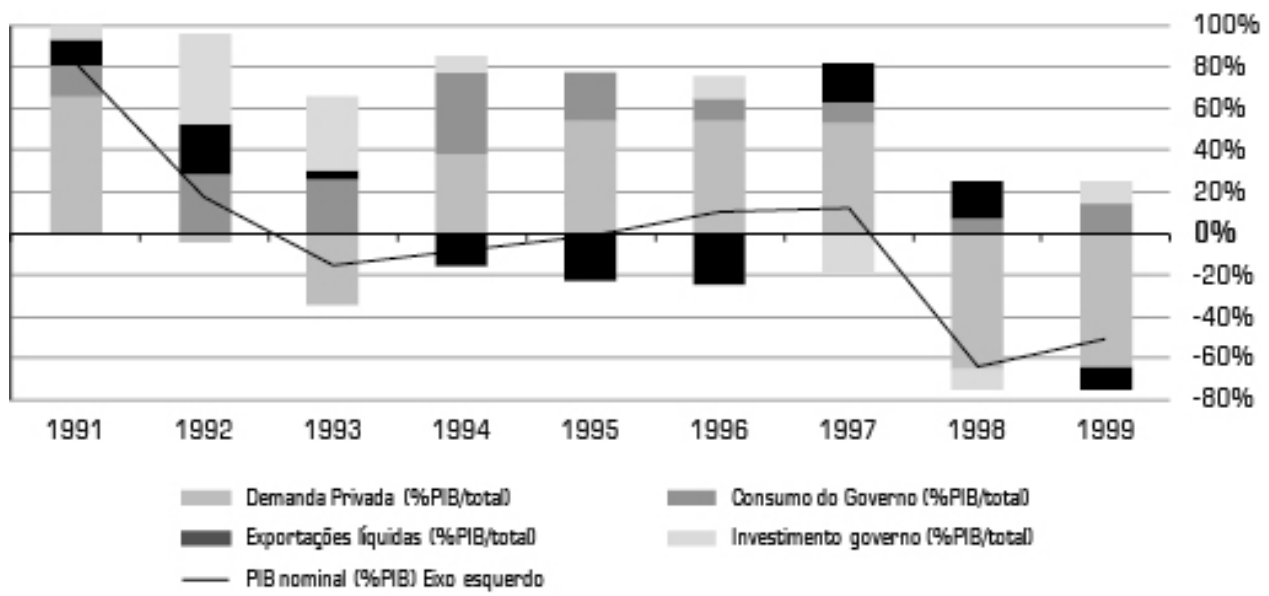

Fonte: Cabinet Office, Japan.

com o fim da bolha, levou à recessão de 1993 e 1994. No entanto, durante a recuperação, a partir de 1994, a demanda privada desempenhou papel maior do que qualquer gasto público ou as exportaçóes líquidas. Foi então que, em 1997, a redução do investimento e consumo públicos, juntamente com a crise no setor bancário, lançou novamente a economia japonesa em recessão, em 1998 e 1999.

$\mathrm{Na}$ década de 1990, a resposta positiva aos estímulos foi minada, então pelas contraçóes fiscais do período; em termos líquidos, a postura fiscal do governo japonês foi, assim, apenas levemente anticiclíca, e os défitics orçamentais acumulados foram o resultado da crise, e não de qualquer resposta discricionária a ela, ou se- ja, o montante de dívida pública adicional assumida foi excessivo, por motivos históricos e também de acordo com os padróes internacionais. De forma geral, os pacotes de estímulos fiscais no Japão, nos anos 1990, consistiram, então, em menos de 60\% do valor anunciado (Posen, 1998).

Um terceiro fator para a baixa eficácia da política fiscal durante a década de 1990 é que os estímulos fiscais podem ter sido prejudicados pela queda dos multiplicadores fiscais. ${ }^{19}$ Estimativas destes multiplicadores demonstram que eles diminuíram, ao longo dos anos. Por exemplo, o Cabinet Office estimou a queda do multiplicador do investimento público para 1,1 em 2004, contra 1,3, em 1991. (Outras estimativas encontram-se na Tabela 3 ).

\footnotetext{
${ }^{19}$ Jinno e Kaneko (2000); Kuttner e Posen (2001); Kalra (2003); Sadahiro (2005).
} 
Tabela 3_Multiplicadores fiscais estimados para o Japão

\begin{tabular}{|c|c|c|}
\hline & Multiplicador & Período de estimação \\
\hline Kalra (2003) & 0,40 & $1981-2000$ \\
\hline Bayoumi (2000) & 0,65 & $1981-1998$ \\
\hline Murata e Saito (2004) & $1,10^{1}$ & $1985-2003$ \\
\hline Kuttner e Posen (2002) & 2,00 & $1976-1999$ \\
\hline
\end{tabular}

Os possíveis fatores que estão por trás do declínio dos multiplicadores fiscais são:

- A ausência de resposta do setor privado. $\mathrm{O}$ consumo privado não respondeu aos estímulos fiscais, porque o setor bancário não foi capaz de desempenhar um papel eficaz na intermediação, dado o fraco balanço dos bancos e os problemas com os maus empréstimos (Kuttner, Posen, 2001; Kang et al., 2009a). Esta interpretação é apoiada por evidências empíricas de uma crise de crédito, durante a década de 1990 (Motonishi; Yoshikawa, 1999). Um número muito grande de empresas estava endividada, não se encontrando em condiçóes de aumentar seus gastos.

- A proporção dos gastos do governo com a seguridade social, que normalmente têm menor peso no multiplicador dos gastos, aumentou de 2,6\% do PIB, em 1990, para 3,5\% do PIB, em 2000 (Haver Analytics). Isto pode ter limitado o impacto dos multiplicadores fiscais, dado o efeito substituição dos gastos públicos.

Percebe-se que a queda dos multiplicadores fiscais está inserida em um complexo de interaçóes, com as mais destacadas pela literatura econômica sendo: a crise no setor bancário, que alterou a relação entre setor bancário e empresarial; o maior direcionamento dos gastos para a seguridade social; a queda no tamanho da força de trabalho, com as taxas de investimento e da produtividade convergindo para níveis consistentes com os de outras economias avançadas, até, então, mais elevadas; e, por fim, as falhas na condução da política fiscal pós-estouro da bolha especulativa, com elevadas compras de terras por parte do governo, demora em reconhecer os problemas do setor bancário e pacotes de estímulos fiscais menores que os anunciados, além das reversóes, em momentos inoportunos, das políticas fiscais.

Por fim, abandonando os argumentos do declínio dos multiplicadores fiscais e de ineficácia da política fiscal como causas da recessão japonesa, alguns autores apon- 
tam para a redução na criação de crédito, que começou em 1992, como o principal fator recessivo, considerando que este problema poderia ter sido resolvido por meio da política monetária, até mesmo sem os empréstimos bancários. O BOJ poderia, segundo eles, ter gerado uma recuperação significativa mediante a criação de crédito próprio; não o fazendo, a recessão do Japão da década de 1990 foi resultado das políticas equivocadas do BOJ (Bernanke, 2000; Werner, 2004). Uma questão importante, como veremos a seguir, é que a demanda por crédito se encontrava deprimida, como ocorre usualmente em recessóes, com o que apenas uma política monetária expansiva, do lado da oferta, estava, para muitos, fadada ao fracasso.

Outra justificativa para o baixo impacto do aumento da dívida pública é que todas as medidas fiscais deveriam ser bem orientadas. Por exemplo, as transferências deveriam ser destinadas às famílias de menor renda, com maior propensão marginal a consumir. Por parte dos investimentos públicos, a prioridade deveria ser dada a projetos mais propensos a estimular a demanda privada (Spilimbergo et al., 2008), e não, como vimos, alguns gastos em ativos não reprodutíveis e, portanto, não geradores de emprego e renda, como terra.

O momento certo para iniciar e encerrar um estímulo fiscal pode ser um de- safio. A experiência japonesa mostrou-se cara, neste sentido, quando, como vimos, em 1997, acreditando na recuperação, as autoridades reverteram a política, retirando os cortes temporários nos impostos de renda e aumentando os impostos sobre o consumo. A economia caiu rapidamente em uma recessão naquele mesmo ano. Uma forma de maximizar os estímulos fiscais seria por intermédio de medidas para a restauração do crédito do setor bancário. Ou seja, os estímulos fiscais poderiam ter sido de curta duração, caso o sistema financeiro estivesse em boa saúde. No Japão, porém, as injeçôes nos bancos "em grande escala” ocorreram apenas em 1999, minimizando a eficácia da política fiscal (Kang et al., 2009a; 2009b).

\section{Política monetária do (BOJ) e sua efetividade na década de 1990}

Com a evoluçáo da crise na economia japonesa, o BOJ enfrentou um conjunto de novos desafios. Após alguns atrasos, a condução da política monetária foi gradualmente flexibilizada, ao longo dos anos 1990, porém os impactos dessa flexibilização foram atenuados, em grande medida, pelas deficiências do setor bancário. Considerando a impossibilidade de reduzir as taxas nominais de juros abaixo 
${ }^{20}$ Entre 1997 e 2006, as taxas de crescimentos de empréstimos dos bancos japoneses tornaram-se negativas. Esse assunto será retomado na próxima seção. de zero, o BOJ tomou algumas medidas inovadoras, a partir de 2001, centradas em uma estratégia para garantir a liquidez e ampliar as garantias nas compras diretas de ativos. Uma quantitative easing policy, perseguindo uma política de taxa nominal quase zero de juros, foi implantada. No entanto, durante quase todo esse período, a política monetária pareceu estar "correndo sobre uma esteira", com a demanda por créditos fraca, e quanto mais as políticas monetárias eram estendidas, menor era a resposta; a economia parecia responder de forma inelástica às medidas.

Com a diminuição do crescimento econômico, as pressões deflacionárias tornaram-se mais danosas; dessa forma, o principal objetivo do BOJ passou a ser evitar a deflação, pelo que esta tem de danoso à rentabilidade prospectiva dos investimentos (em uma comparação entre a eficácia marginal do capital e as taxas de juros de ativos financeiros com prazos e outras condiçóes similares - Keynes, 1936). As primeiras respostas do BOJ à crise se deram por meio da ferramentas-padrão de política monetária, ou seja, de sucessivas reduçóes da taxa de juros, com o $\mathrm{BOJ}$ a reduzindo gradualmente, de meados de 1991, até estabilizá-la, em 1996, em $0,5 \%$ ao ano e, em fevereiro de 1999 , anunciando "formalmente para o mercado" a mudança (radicalização) de sua política para uma taxa de juros nominais praticamente nulos. De fato, em 2001, alcançou-se uma taxa de juros de $0,02 \%$ ao ano, a qual foi elevada, ao final de 2006, para próximo a $0,5 \%$ ao ano. O BOJ objetivava com essa medida estimular a retomada do nível de atividade, criando condiçóes para que a demanda interna fosse aquecida.

Em 1997, com o colapso de algumas das principais instituições financeiras do país, o ambiente macroeconômico deteriorou-se significativamente, reduzindo-se liquidez de um modo generalizado. ${ }^{20}$ Isto demandou ações mais incisivas para facilitar as condiçóes de crédito, embora as ferramentas de política monetária encontrassem-se limitadas, com as taxas básicas de juros próximas a zero e os rendimentos dos títulos públicos de longo prazo abaixo de $2 \%$ ao ano. A despeito deste quadro, havia grande necessidade de mudanças na condução da política monetária.

A primeira delas ocorreu no ambiente institucional, com a aprovação da independência "formal" do Banco Central Japonês (BOJ), em relação ao governo. Ademais, a fim de dar suporte à liquidez e substituir o frágil mercado interbancário, o BOJ flexibilizou seus instrumentos básicos de política monetária, criando outros canais de crédito. Os principais focos dessas medidas foram: 
1_aumentar o número de colaterais aceitáveis, incluindo títulos privados, empréstimos em ações, asset-backed commercial paper (ABCP) e outras formas de asset-backed securities (ABS);

2_proporcionar liquidez em prazos maiores, estendendo a maturidade das bill purchases e títulos do governo japonês (JGB), com o acordo de recompra passando de seis meses para um ano;

3_aumentar o número de contrapartidas, operaçóes de reposição, para as compras dos (JGB) e commercial papers. Como resultado dessas políticas, houve inchaço no balanço do BOJ, mas com aumento da liquidez da economia japonesa.

A compressão das taxas de juros da economia para zero, paradoxalmente, fez com que as margens de lucro do setor bancário caíssem, em razão da queda da rentabilidade esperada dos novos empréstimos, mesmo com esta queda nos custos dos novos passivos. Esses novos empréstimos deixaram, então, de ser rentáveis, prospectivamente, tornando-se praticamente impossível para os bancos japoneses, por conta própria, retirar de seus balanços os empréstimos problemáticos. Em muitos países com os mesmos problemas de "crédito podre", as margens entre as taxas de depósitos e as taxas de empréstimos sofreram acréscimos; com isso, os bancos, através de novos empréstimos, foram capazes de se recuperarem gradualmente das perdas com os empréstimos ruins (Goyal, McKinnon, 2003). Na economia japonesa, no entanto, esse diferencial tem sido baixo, dificultando os bancos com problemas de no-performing loans a obterem lucros, os quais poderiam ser utilizados na recuperação de seus capitais. Para Goyal e McKinnon (2003), esta é uma das causas para a queda no crédito bancário para o setor privado, ao menos durante a década de 1990.

Não obstante, outra leitura é feita neste artigo. No Japão, os declínios acentuados dos preços das terras e das ações deixaram as empresas tecnicamente insolventes: o valor dos ativos caiu enquanto os passivos permaneceram inalterados, fazendo com que o patrimônio líquido se tornasse negativo. No setor bancário, o principal efeito foi o descasamento entre o valor dos empréstimos e o valor das garantias dadas aos bancos sob a forma de ativos imobiliários. Nesse contexto, a reversão das expectativas tornou inviável uma série de projetos de investimentos, em sua maioria financiados com recursos captados nos bancos. Os empréstimos tornavam-se impagáveis, ao mesmo tempo em que o valor das garantias ofertadas sob a 
forma de ativos imobiliários correspondia, agora, a uma fração cada vez menor dos montantes tomados como empréstimos.

Essas empresas teriam, então, deixado o setor bancário japonês inteiro insolvente, continuando em funcionamento sem serem forçadas a reestruturar as suas obrigaçóes - o objetivo era manter o fluxo de caixa e refinanciar as dívidas a juros cada vez mais baixos. Assim, os créditos novos não foram estimulados, mesmo com taxas de juros zero, o que é explicado pela baixa demanda (devedores insolventes) ${ }^{21}$ e pela necessidade de reestruturação do setor bancário, dadas as perdas com os no-performing loans. ${ }^{22}$

Em março de 2001, com a implantação da política de quantitative easing, o instrumento de política foi alterado, com o BOJ elevando o volume de reservas do setor bancário, mediante operações de mercado aberto e compras de títulos do governo diretamente do mercado secundário. Tratava-se de uma expansão da base mo- netária, mesmo quando a taxa básica de juros náo podia ser abaixada, quer através de operaçóes de mercado aberto sobre a dívida pública, quer por meio de compras de títulos de longo prazo (ou açóes). Para Kregel (2009), uma versão convencional da armadilha da liquidez levou autores como Krugman e Bernanke a proporem ao Banco do Japão realizar uma política de expansão de reservas, conhecida como "quantitative easing", a fim de tentar produzir inflaçáo ou, pelo menos, aumentar a expectativa inflacionária de forma suficiente para produzir taxas reais de juros negativas.

A meta inicial das compras foi fixada em cerca de $¥ 5$ trilhóes, com o objetivo de empurrar a taxa do overnight ${ }^{23}$ para zero, sendo aumentada uma série de vezes para próximo de $¥ 35$ trilhóes, até 2004. Todavia, ao contrário das expectativas dos economistas do mainstream economics, ${ }^{24} \mathrm{o}$ crescimento dos empréstimos bancários permaneceu negativo. Adicio-

\footnotetext{
${ }^{21}$ Para uma análise empírica das empresas "zumbis", ver Caballero, Hoshi e Kashyap (2008).

${ }^{22}$ A relação estreita entre bancos e empresas com alto volume de participação acionária cruzada, entáo, perde a sua força com: a) a abertura financeira,
}
b) o colapso das bolhas especulativas e c) a crise bancária de 1997.
${ }^{23}$ A título de exemplo, no caso brasileiro, a taxa de overnight do Sistema Especial de Liquidação e de Custódia (SELIC), expressa na

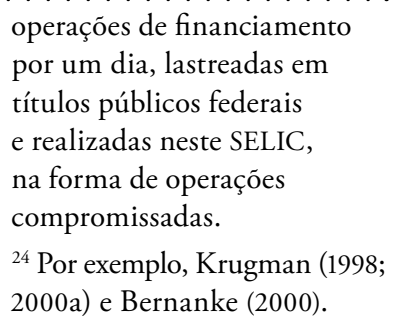
forma anual, é a taxa média ponderada pelo volume das 
nalmente, uma maior coordenação com a política fiscal esteve também presente, com o BOJ aumentando gradualmente as suas compras de JGBs de longo prazo, de $¥ 400$ bilhóes para ¥ 1,2 trilhões por mês, com essas compras sendo, no geral, vistas pelo mercado como um curativo sobre os rendimentos de longo prazo (Kang et al., 2009a), ao sinalizar para taxas baixas de juros e prazos mais longos.

Com o passar do tempo, os ativos que poderiam ser comprados pelo BOJ sob a quantitative easing policy foram expandidos, incluindo, como vimos, commercial papers, títulos corporativos, ações e asset-backed securities. ${ }^{25}$ A política de quantitative easing elevou o balanço do BOJ de $¥ 91$ trilhóes, em 1998, para cerca de $¥ 155$ trilhôes, em 2006. Paralelamente a tais açóes, o BOJ tomou medidas inovadoras, a fim de enfrentar a escassez de capital dos bancos, pois, com cerca de $150 \%$ de seu capital (Tier 1$)^{26}$ limitados, a capacidade de estender crédito e assumir novos riscos havia sido restringida. Para ajudar a reduzir a exposiçáo dos bancos no mercado, o BOJ introduziu um programa, em 2002, para a compra de equities, diminuindo de A para BBB a exigência mínima para aceitação de bônus corporativos como garantias indiretas ou diretas dos bancos a preço de mercado. Durante 2002 e 2004, as compras de ações realizadas pelo $\mathrm{BOJ}$ atingi- ram $¥ 2,1$ trilhóes, representando cerca de 6\% do total do capital dos bancos. Apesar de significativa, a quantidade foi pequena em comparação com a participação do BOJ na compra dos JGBs, de ¥ 65 trilhóes (Kang et al., 2009a; 2009b).

O BOJ também recorreu a medidas não convencionais para apoiar os empréstimos ao setor privado. Em 1998, ajudou empresas com dificuldades com os seus financiamentos que venceriam no final daquele ano, estabelecendo um mecanismo temporário de empréstimo, o qual facilitava o refinanciamento de 50\% dos aumentos dos empréstimos concedidos pelas instituiçóes financeiras, durante o quarto trimestre de 1998. Em 2003, o BOJ iniciou um programa de apoio às pequenas e médias empresas (PMEs), através de compras de commercial papers (ABCP) e Asset Backed Security (ABS) lastreados em empréstimos às PMEs, avaliados como BB (a exigência mínima de aceitação) ou superior. Além disso, em 2003 e início de 2004, o Ministério das Finanças (MOF) empreendeu intervençóes cambiais em grande escala, estabilizando o iene em um período de baixa do dólar. As quantias foram elevadas, com as autoridades monetárias vendendo $¥ 20$ trilhões, em 2003, e ¥ 15 trilhões, no primeiro trimestre de 2004. Essa agressiva intervenção cambial, principalmente em

\footnotetext{
${ }^{25}$ Para Kang et al. (2009a; 2009 b), os valores reais dessas operaçôes foram, contudo, relativamente limitados.

${ }^{26}$ A relação de capital dos grandes bancos refere-se à Tier 1 , que é a relação de capital essencial, quando comparada ao total de ativos. É a principal medida de solidez financeira de um banco.
} 
2003 e 2004, auxiliava na proteção da política monetária contra choques externos, mas não alcançou a depreciação esperada do iene: em 2003, \$1= ¥115,93; em 2004, $\$ 1=¥ 108,19$, e em 2005, \$1= ¥110,21. Manteve-se, porém, o câmbio estabilizado, no período.

A quantitative easing náo freou imediatamente a deflação e também não conduziu a uma expansão no crédito bancário, refletindo, em parte, a tímida demanda por crédito, por parte das empresas, em um período de elevadas pressóes de desalavancagem e de um setor bancário ainda frágil (Gráfico 6).

Para Ito e Mishkin (2004), mesmo com todo o empenho, o BOJ não conseguiu

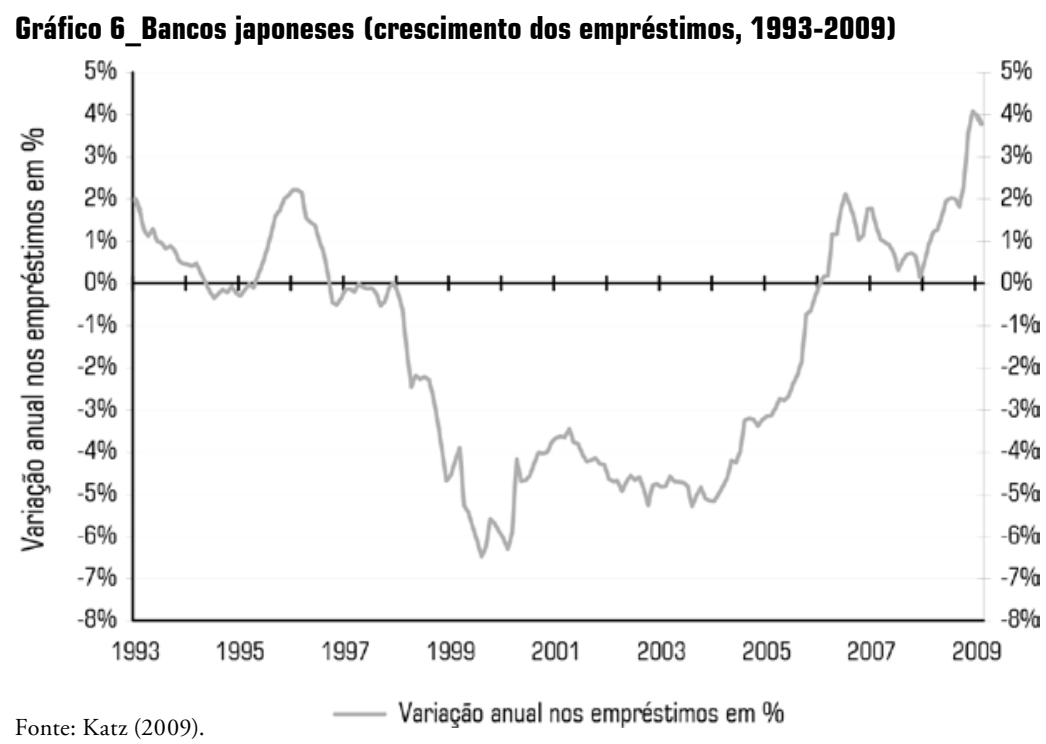

acabar com a deflação, dado que os agentes criaram expectativas de que, mesmo quando exercia uma política monetária expansiva, não tardaria a revertê-la. Assim, não seria uma surpresa que a quantitative easing não funcionasse. $\mathrm{Na}$ verdade, a economia japonesa encontrava-se basicamente deflacionária, de forma contínua, durante quase toda a década de 2000.

Assim, as respostas à política monetária conduzida pelo BOJ, durando os anos 1990, provaram-se fracas, quando se avalia a evolução econômica, dado o declínio nos preços e produção. A necessidade de elaboraçáo de novos procedimentos operacionais, para um ambiente de taxa de juros zero, pode ter sido um fator restritivo. No período em que a quantitative easing policy foi implantada, os preços já estavam em uma trajetória descendente e com os rendimentos realizados e prospectivos de longo prazo deslocados para níveis muito baixos; ademais, os prematuros apertos da política fiscal e a ausência de melhor coordenação entre estas políticas podem ter prejudicado a eficácia da política monetária.

As políticas de taxas de juros zero e quantitative easing produziram, desta forma, custos elevados, mas sem apresentar uma solução definitiva. Por exemplo, a ampla liquidez e as baixas taxas de juros podem atrasar o reconhecimento dos empréstimos 
problemáticos e afetar a reorganização do mercado financeiro, tornando mais fácil para os devedores insolventes maquiarem suas verdadeiras situaçôes, mantendo-se regulares nos seus pagamentos de juros. $\mathrm{E}$ o achatamento da curva de rendimentos também tornou mais árdua, para o setor bancário, a tarefa de aumentar sua rentabilidade e crescer, contornando os problemas dos no-performing loans (Kang et al., 2009a; 2009b).

\section{5_Fragilidade do setor bancário japonês e políticas}

Com a intensificação da crise, suas raízes se tornaram mais claras e o governo japonês passou a direcionar políticas ao sistema financeiro, centrando-as na reestruturação dos bancos. O objetivo foi forçá-los a reconhecer os empréstimos não realizáveis (no-performing loans) e erguer novamente capital ou, em alguns casos, demandar fundos públicos ou, ainda, sair do setor. As perdas bancárias foram muito maiores do que o imaginado (mais de US\$ 1 trilhão), sendo que aproximadamente $¥ 47$ trilhóes de fundos públicos foram necessários para eliminar estes no-performing loans e recapitalizar os bancos.

A partir de 1991, o governo japonês embarcou em uma série de tentativas para resolver os problemas no setor bancário.
Várias empresas imobiliárias especializadas em empréstimos (Torjusen) e cooperativas de crédito apresentavam dificuldades, e o governo, através dos bancos privados, reforçou a concessão de empréstimos, concedendo maior liquidez a estas empresas. Entretanto, com a queda contínua nos preços dos imóveis, as perdas com os empréstimos elevaram-se. Em 1995, cerca de $75 \%$ dos empréstimos das Torjusen tornaram-se no-performing, o que forçou o governo a liquidar as Torjusen falidas e criar uma empresa pública para administrar os ativos ruins (Hoshi, Kashyap, 1999; 2001). Um dos principais efeitos da queda dos preços dos ativos sobre o setor bancário foi o usual descasamento entre o valor dos empréstimos e o valor das garantias dadas aos bancos, sob a forma dos ativos imobiliários. Os empréstimos tornavam-se, conseqüentemente, impagáveis, ao mesmo tempo em que o valor das garantias, sob a forma de ativos imobiliários, passava a corresponder a uma fração cada vez menor dos montantes tomados.

A experiência de crises bancárias anteriores indica que a natureza, velocidade e ordem de implementação de políticas pelo poder público podem determinar a magnitude e o custo da crise. Percebe-se que é necessário realizar as seguintes tarefas: primeiro, recapitalizar o setor bancário. Segundo, revigorar a atividade econômi- 
${ }^{27}$ Em parte repetida, a partir de setembro de 2008, nos EUA.

${ }^{28}$ Cerca de $30 \%$ dos estoques de empréstimos externos dos bancos japoneses, em 1997, encontravam-se em países do Sudeste da Ásia. ca por meio de medidas fiscais adequadas (Morjon et al., 2008). No Japão, a tendência inicial foi de inércia e de falta de entendimento sobre as conseqüências da morosidade e insuficiência da atuação governamental sobre o sistema, ${ }^{27}$ assim como da crença de que a recuperaçáo econômica viria "naturalmente", com o passar do tempo. Também a resistência pública à ajuda aos bancos, juntamente com as deficiências do sistema de seguro de depósitos e a ausência de um quadro jurídico para a resolução de uma crise bancária de grande escala, pode ter limitado a capacidade de ação das autoridades (Kanaya, Woo, 2000).

Dessa forma, os empréstimos problemáticos foram autorizados a apodrecer, com os custos dos financiamentos para os bancos japoneses elevando-se cada vez mais, na metade da década de 1990 . Depois de 1995, quando explodem os problemas das Torjusen, e de 1997, com a crise asiática, ${ }^{28}$ os custos dos empréstimos aos bancos japoneses elevam-se, até o início de 2000. As perdas bancárias com os no-performing loans mudaram, de uma quantidade insignificante, em 1993, para aproximadamente 20\% do PIB japonês, de 2005 a 2008 (Katz, 2009), quando parecem ter se estabilizado em seu nível máximo (Gráfico 7).

De modo geral, portanto, a fragilidade do sistema financeiro, aliada ao longo cenário difícil macroeconômico, não possibilitaram uma reestruturação rápida das instituições financeiras. A inadimplência

\section{Gráfico 7_Perdas acumuladas de empréstimos dos bancos japoneses desde 1992}

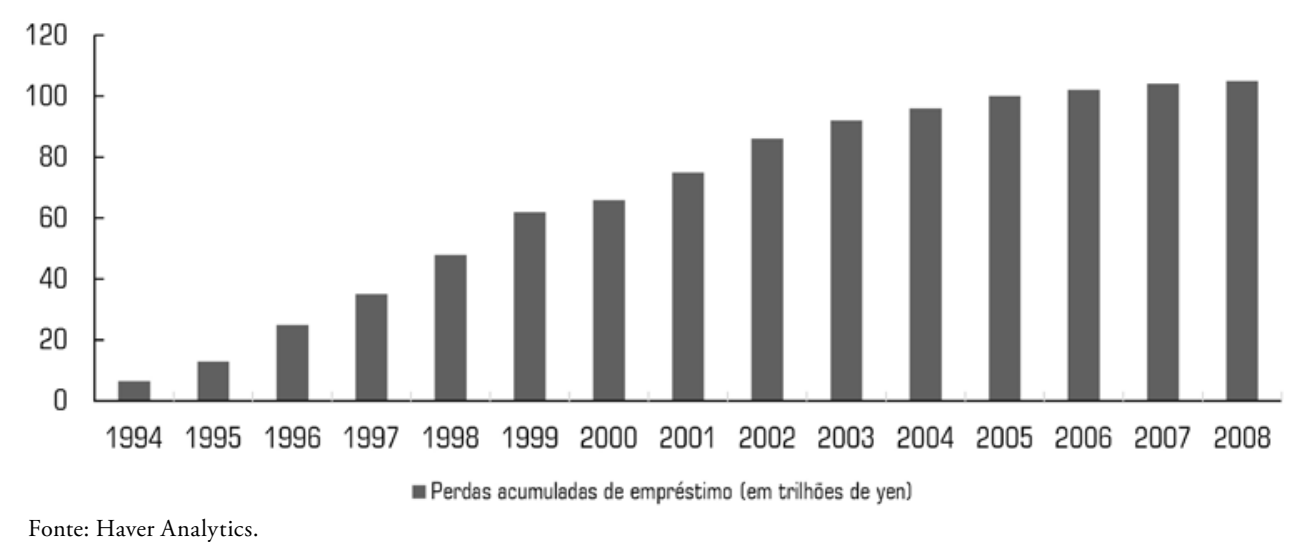


ampliou-se ainda mais, pela redução dos fluxos de renda das empresas, as quais, em muitos casos, passaram a não suprir o serviço de suas dívidas. Vale dizer, as empresas se viram, de repente, transportadas de posições hedge para posiçóes especulativas ou mesmo Ponzi, em termos minskyanos (Minsky, 1986).

Outro fator agravante foi que as carteiras de empréstimos se tornaram ainda mais ilíquidas, já que, com a desvalorização das ações e das terras, as garantias (colaterais) oferecidas perderam valor. $\mathrm{E}$, em condiçóes críticas, os riscos provenientes destas carteiras podiam rapidamente se transformar de risco de liquidez para risco de solvência (Zendron, 2006).

Com o aumento das tensóes no mercado financeiro, em 1997, o BOJ foi obrigado a intervir para estabilizar o sistema. Falências sucessivas de vários bancos $\mathrm{e}$ títulos imobiliários paralisados no mercado exigiram medidas de emergência, a partir da metade da década de 1990 . O BOJ assumiu o seu papel de emprestador de última instância e apoiou o mercado interbancário, com injeção direta de capital em bancos falidos e também através da Deposit Insurance Corporation (DIC), ${ }^{29}$ comprando ativos bancários. Estas medidas não foram suficientes, entretanto, com as tensóes intensificando-se e levando o BOJ e o Ministério das Finanças
(MOF), em novembro de 1997, a anunciarem uma garantia geral sobre todos os depósitos e operaçóes interbancárias, a fim de protegerem o setor. A partir de 1998, o nível de capital dos bancos permanecia limitado, com volatilidade e nível da taxa de juros de curto prazo reduzidos e os spreads dos bancos japoneses muito baixos, ou seja, com a capacidade de estender crédito novo ou assumir os riscos dos bancos também diminuta. A frágil regulamentação sobre a concessão de novos empréstimos também reduziu o incentivo dos acionistas para tomarem medidas saneadoras, seja através de novos empréstimos, seja da retirada dos no-performing loans dos balanços dos bancos. Para resolver esse impasse, o BOJ e outras instituições incentivaram o governo japonês a injetar fundos públicos, como meio de liberar as restriçôes de capital dos bancos e revitalizar o canal de crédito.

Há algumas razōes para o atraso na elaboração e implementação de ações decisivas. Em primeiro lugar, a abordagem inicial adotada, entre 1991 e 1997, foi baseada na expectativa de que uma retomada do crescimento econômico viria sem demora e devolveria a saúde financeira aos bancos e às empresas envolvidas com os no-performing loans. Era também esperada a recuperação dos preços das terras e de sua trajetória de crescimento.

\footnotetext{
${ }^{29}$ Em 1997, o BOJ injetou US\$ 35 bilhóes, como emprestador de última instância, e US\$ 74 bilhôes, em empréstimos, à Deposit Insurance Corporation (DIC), para a recapitalização dos bancos. Em 2001, o total de créditos perdidos (incobráveis) foi estimado em US\$900 bilhões. Ver Nakaso (2001), para as primeiras respostas políticas à crise.
} 
O colapso nos preços dos ativos do final dos anos 1980 foi o primeiro na história japonesa pós-guerra, o que também levou à demora em reconhecer a situação como uma bolha especulativa. Até o estouro desta bolha, havia forte convicção do chamado "mito da terra", ou seja, os preços das terras nunca iriam declinar. A política inicial adotada pelo Ministério das Finanças (MOF) se destinava, então, a proteger os bancos com dificuldades, por meio de tolerância e outras formas de apoio, enquanto ganhava tempo na esperança na retomada do crescimento econômico e dos preços dos ativos. No entanto, com a falência do banco Toho Sogo, em 1991, e as falências de pequenas instituições financeiras, entre 1994 e 1995, essas expectativas favoráveis se modificaram. Em 1995 e 1996, o governo injetou fundos públicos nas Torjusen. Esta política foi duramente criticada na Câmara e mostrou-se politicamente impopular, desanimando o MOF a fazer mais uso de fundos públicos nos balanços dos bancos. Assim, o governo, no primeiro momento, esforçou-se para conter as dificuldades emergentes do setor bancário, sem o uso de fundos públicos, apenas realizando política fiscal através da redução nos tributos, medida menos impopular, porém de menor resultado na soluçáa dos problemas patrimoniais das empresas e bancos.
As primeiras tentativas de recapitalização pública emergiram, contudo, com algumas condiçóes. Um comitê para a administração da crise financeira foi criado, a fim de identificar os bancos com escassez de capital e os montantes a serem injetados. Foram definidas as condiçóes às quais os reguladores deveriam aplicar açóes corretivas, com a tolerância regulatória estreitando-se. Nesse novo cenário, a injeção de fundos públicos aconteceu em três fases: em fevereiro de 1998, o governo lançou $¥ 30$ trilhóes em fundos públicos, dos quais $¥ 13$ trilhóes (cerca de 2,5\% do PIB) foram para injeção de capital em bancos solventes e com o restante rumando para a proteção dos depósitos dos bancos falidos. Mas esses pacotes não foram suficientes, dado que apenas $¥ 1,8$ trilhão foi injetado em 21 grandes bancos, entretanto, sem um minucioso exame ou limpeza de seus balanços.

O mercado continuou a deteriorar-se e, em outubro de 1998, os valores dos fundos públicos destinados a reforçar o setor bancário foram dobrados para $¥ 60$ trilhões (12\% do PIB), dos quais ¥ 25 trilhóes foram reservados para os bancos solventes e o restante para resolver o problema dos depósitos dos bancos falidos. Esta estratégia foi complementar às anteriores, porém, no que diz respeito à regulamentação e ao exame dos no-performing loans 
nos balanços dos bancos, foram tomadas medidas mais rigorosas, concentrando-se em quatro elementos-chave:

- Garantir a avaliação realista dos ativos podres. A estratégia começou com a inspeção especial da Agência de Serviços Financeiros (FSA), concentrando-se nos grandes devedores, grandes bancos e, posteriormente, nos bancos regionais.

- Acelerar a eliminação dos noperforming loans. Com o Program for Financial Revival, os grandes bancos foram obrigados a acelerar a eliminação da inadimplência de seus balanços, dentro de dois a três anos, e vendê-los diretamente no mercado, prosseguindo com os processos de falência ou reabilitando os mutuários através de medidas sem a necessidade de recorrer a tribunais. Os restantes dos empréstimos foram vendidos à Resolution and Collection Corporation (RCC).

- Melhorar o capital dos bancos. Aproximadamente $¥ 12,5$ trilhóes dos fundos públicos (incluindo as injeçóes passadas) foram utilizados para recapitalizar os grandes bancos (exceto o Grupo Financeiro Mitsubishi Tokyo) e os bancos regionais, principalmente através da aquisição de açóes preferenciais ou dívida subordinada (não cobertas por garantias reais ou flutuantes). Os bancos foram obrigados a empreender reformas consistentes com as orientaçóes do Acordo de Basiléia, ${ }^{30}$ com a nomeação de diretores externos e estabelecendo uma comissão de auditoria mais rígida.

- Controle reforçado. Em 1998, a FSA foi criada (mais tarde renomeada para Agência de Serviços Financeiros), consolidando a supervisão do Ministério das Finanças (MOF) e outras agências governamentais, em uma única entidade. Uma nova lei também foi aprovada, autorizando a FSA a prescrever regras prudenciais e aplicar medidas corretivas imediatas, quando as regras fossem violadas ou as instituições vistas como perigosas ou instáveis.

Em 2003, o governo oficializou a Industrial Revitalization Corporation of Japan (IRCJ) para a aquisição de empréstimos de bancos com dificuldades (até próximo a $¥ 1$ trilhão por banco) e a ajuda aos devedores na reestruturação. Para apoiar o setor privado, levando-o a uma

\footnotetext{
${ }^{30}$ Nesse período, a maior parte dos bancos japoneses continuava fora dos critérios de adequação de capital do Acordo de Basiléia, o que gerava preocupaçóes do mercado sobre a qualidade e capacidade de adequação de capital desses bancos, para absorver possíveis perdas adicionais (Tonooka, 2004).
} 
reestruturação, o governo também reforçou o sistema de insolvência (introdução de uma forma mais rápida e eficiente, via "Civil Rehabilitation Law"), orientando os órgãos corporativos para uma solução amigável fora dos tribunais e atualizando o quadro de contabilidade e auditoria. Estas medidas ajudaram a criar um mercado para a reestruturação dos ativos ruins, atraindo capital privado e perícias, inclusive do exterior.

Por fim, o governo japonês injetou recursos públicos, aproximando-os da quantia de $¥ 47$ trilhôes (algo em torno de $10 \%$ do PIB de 2002), a fim de recapitalizar o setor bancário e eliminar os empréstimos problemáticos. Em 2003, os preços das açóes dos bancos começaram a se recuperar, com a inadimplência apresentando uma tendência de queda, em comparação com os empréstimos totais e também com a relação de capital dos bancos crescendo (Hoshi, Kashyap, 2008; Kang et al., 2009b).

Vale dizer, dez anos após o início da crise, o setor bancário sofreu significativa consolidação, com diversos bancos de grande porte e muitas instituiçóes menores fechando ou se fundindo. Até o primeiro semestre de 2009, quase $75 \%$ dos fundos públicos ( $¥$ 12,5 trilhóes) injetados na economia foram reembolsados e a expectativa é de que $80 \%$ do total dos fundos sejam recuperados (Deposit Insurance Corporation of Japan, 2006).

\section{6_Considerações finais}

Por muitos anos, práticas contábeis duvidosas e uma fraca regulamentação mascararam o problema da morosidade e dos limitados incentivos às medidas corretivas. Em parte, como vimos, isto refletia a falta de compreensão do problema dos no-performing loans e a esperança que a recuperação viria naturalmente, sem grandes intervençōes. No entanto, a demora em reconhecer os problemas provou-se dispendiosa, não apenas ou principalmente para os contribuintes, devido aos fundos públicos injetados na economia, mas por atrasar a recuperaçáo e a retomada do crescimento econômico, e aumentar a incerteza sobre a saúde dos balanços dos bancos.

Quando um setor bancário está falido, os multiplicadores monetários deixam de funcionar adequadamente. A eficácia das políticas monetária e fiscal é comprometida. A restauraçáo do sistema de crédito torna-se prioritária. No caso japonês, isto significava enfrentar os problemas dos no-performing loans.

Nessa perspectiva, de um setor bancário frágil e um sistema regulador brando, os bancos comerciais continuaram emprestando às empresas "zumbis", as quais 
não tinham condições de cumprir com seus acordos financeiros, estando, entáo, tecnicamente falidas, prática que contribuiu para aumentar o volume dos no-performing loans. Esta má distribuiçáo dos créditos ocorreu em resposta aos incentivos que vieram de políticas governamentais pouco transparentes e acomodatícias (Peek, 2004).

A injeção de fundos públicos em instituições viáveis, juntamente com as fusóes e fechamento das instituiçóes inviáveis, ajudou a recuperar o crédito e fortalecer a relação de capital, mas isto só após o reconhecimento dos no-performing loans, com o apoio e acompanhamento da FSA, sob um plano de recuperação acordado. As compras e vendas pelo governo dos no-performing loans, através da RCC e da IRCJ, facilitaram a reestruturação do mercado, ampliando informações sobre preços, resolvendo disputas por créditos e proporcionando melhores prestaçóes de conta e clareza jurídica. ${ }^{31}$

De modo geral, até março de 2007, a DICJ havia injetado na economia US\$ 399 bilhões, dos quais US\$ 159 bilhões na forma de subsídios, US\$ 83 bilhóes na compra de ativos (compra de ativos de empresas falidas e ações de bancos sob administração pública), US $\$ 106$ bilhôes em injeçôes de capital, e US\$ 51 bilhóes em outras assistências, na maioria emprésti- mos. A última injeção de capital da DICJ foi em março de 2003. A partir desta data, a Resolution and Collection Corporation (RCC) comprou ativos da DICJ e de instituições financeiras sob a administração pública. A RCC deixou de fazer compras em março de 2006 (Deposit Insurance Corporation of Japan, 2006).

A experiência do Japão, após os colapsos das bolhas especulativas dos ativos na década de 1990, mostra os dilemas de política econômica que se apresentam nos períodos de turbulência e tensóes financeiras agudas. Não obstante, uma solução é necessária para uma recuperação sustentada, seja através de política fiscal e monetária, seja por meio de políticas especificamente direcionada ao setor bancário. Neste contexto, uma abordagem abrangente, que trate tanto a solvência do sistema quanto sua liquidez, pode ser necessária, acompanhada de uma reestruturação das dívidas dos mutuários em dificuldades.

No entanto, para apoiar o crescimento nas economias com capacidade efetiva para executar tais açóes discricionárias, os estímulos fiscais devem ser mantidos, centrados em áreas de maiores impactos, revertendo-se apenas quando os sinais de recuperação sustentada forem claros. Ao mesmo tempo, é importante articular uma estratégia concreta para o retorno a uma posição fiscal sus-

\author{
31 Para uma análise do \\ desenvolvimento desse \\ mercado, cf. Kang (2003) e \\ Ohashi e Singh (2004).
}


tentável, no médio e longo prazos, assim, simultaneamente, mantendo a confiança na moeda, restaurando os mercados de crédito e combatendo eventuais processos deflacionários. Ações de política monetária também são necessárias, devendo ser ousadas, inovadoras e amplas. Dessa forma, quando as medidas facilitadoras de crédito são tomadas, os potenciais prejuízos, ao menos temporários, para o balanço e a credibilidade do Banco Central, devem ser cuidadosamente administrados. Neste cenário, uma comunicação transparente entre Banco Central e agentes do mercado é indispensável, incluindo uma estratégia para a interrupção definitiva dos estímulos.

A experiência de crises bancárias anteriores, porém, deveria ter indicado que a natureza, a velocidade e a ordem em que o poder público implementa medidas pode determinar a magnitude e o custo da crise. Portanto, em retrospectiva, percebe-se que era necessário realizar as seguintes tarefas: primeiro, recapitalizar o setor bancário; segundo, restaurar o crédito; e terceiro, temporariamente revigorar a atividade econômica, através de medidas fiscais adequadas. A demora em reconhecer as perdas com empréstimos problemáticos comprovou-se cara à economia japonesa, visto que o resultado foi um longo período de estagnação e, mes- mo assim, com aumento da dívida pública, o qual se deu produzindo menos resultados do que teria sido possível com uma ação mais rápida.

Outros fatores relevantes que contribuíram para esse longo período de estagnação foram: o baixo desempenho de um número elevado de empresas "zumbis", tecnicamente falidas, por causa de seus baixos pagamentos de dividendos, jogou o setor bancário japonês na crise de 1997. A queda na evolução do desempenho da força de trabalho, com taxas de investimento e de produtividade convergindo para níveis consistentes com os de outras economias avançadas, também contribuiu, além de falhas na condução da política fiscal, ou seja, os limitados impulsos fiscais adotados, em particular as prematuras reversóes fiscais, com natureza stop-and-go dos estímulos realizados. Outros fatores prováveis para a baixa eficácia da política fiscal durante os anos 1990 foram que os estímulos fiscais podem ter sido prejudicados pela queda dos multiplicadores fiscais; pelos investimentos públicos efetivos terem sido menores que os anunciados; e pela priorizaçáo de cortes em impostos, em vez de se dar ênfase a obras públicas. Ademais, como vimos, erros na condução da política fiscal contribuíram para a queda dos multiplicadores.

Sobre a condução da política monetária, esta, após alguns atrasos, foi gra- 
dualmente flexibilizada, ao longo dos anos 1990. Centrada em uma estratégia para garantir a liquidez e ampliar as garantias, nas compras diretas de ativos, foi implantada uma quantitative easing policy, com uma política de taxa zero de juros e crédito ilimitado, disponível praticamente a todas as instituiçôes bancárias. No entanto, durante quase todo esse período, a política monetária pareceu estar "correndo sobre uma esteira", com a demanda por créditos permanecendo fraca. Ademais, a compressão das taxas de juros da economia para zero fez com que a margem de lucro do setor bancário caísse e os novos empréstimos do setor deixassem de ser rentáveis, tornando-se praticamente impossível para os bancos japoneses, por conta própria, livrarem-se dos empréstimos ruins em seus balanços. Portanto, as políticas de taxas de juros zero e de quantitative easing tiveram custos elevados, sem conduzir a uma solução definitiva, sobretudo do lado da demanda por créditos.

Do lado do setor bancário, uma administração centralizada dos ativos ajudou a acelerar a limpeza dos balanços dos bancos. As compras e vendas dos no-performing loans através da Resolution and Collection Corporation (RCC) e da Industrial Revitalization Corporation of Japan (IRCJ) facilitou esta reestruturação, reajustando preços de ativos.
A resposta para o porquê de as políticas fiscais e monetárias não terem conseguido combater o longo período de estagnação, mesmo quando o BOJ baixou as taxas de juros de forma bastante agressiva, por aproximadamente duas décadas, a partir dos anos 1990, pode ser dada, então, resumidamente, pela morosidade da atuação do governo japonês, do ponto de vista fiscal, acentuada pela má condução das políticas fiscal, quando adotada, e monetária. Mas, também, devido às políticas “orientadas" para o setor bancário só terem sido adotadas dois anos após a crise de 1997. 


\section{Referências bibliográficas}

BANK OF JAPAN. Comparative economic and financial estatistics Japan and other major countries. Bank of Japan, 1999.

BERNANKE, BEN. S. Japanese monetary policy: A case of self-induced paralysis? In: RYOICHI, Mikitani; POSEN, Adam S. (2000). Japan's financial crisis and its parallels to US experience. Special Report 13, September. Institute for International Economics, Washington, D.C., 2000.

CABALLERO, RICARDO J.; HOSHI, TAKEO; KASHYAP,

K. ANIL. Zombie lending and depressed restructuring in Japan. American Economic Review, vol. 98, p. 1943-077, Dec. 2008.

CABINET OFFICE, JAPAN. Statistics online. 2010. Disponível em: <http://www.cao.go.jp/index-e. html>. Acesso em: 10 jan. 2010.

DEPOSIT INSURANCE CORPORATION OF JAPAN. Annual Report 2006. p. 70. Disponível em: <http://www.dic. go.jp/english/e_annual/e_annual. html >. Acesso em: 5 dez. 2009.
FRAGA, JEFFERSON. S. A crise econômica no Japáo após os anos 90. Dissertação (Mestrado em Economia) - Faculdade de Ciências e Letras da UNESP, 100p. Araraquara. Araraquara, 2011.

\section{GERLACH, M. Keiretsu} organization in the Japanese economy: Analysis and trade implications. In: JOHNSON, C.; TYSON, L.; ZYSMAN, J. Politics and productivity: The real story of why Japan works. Harper Business, 1989.

GOYAL, R.; MCKINNON, R. (2003) Japan's negative risk premium in interest rates: The liquidity trap and fall in bank lending. Blackwell Publishing Ltd 2003, 9600 Garsington Road, Oxford, OX4 2DQ, UK and 350 Main Street, Malden, MA 02148, USA.

HAVER ANALYITICS. Economic \& Financial Databases. Disponível em: <http://www.haver.com/>. Acesso em: 4 set. 2009.

\section{HERMANN, JENNIFER. Da}

liberalização à crise financeira

Norte-Americana: a morte anunciada chega ao Paraíso. Dossiê da Crise. Associação Keynesiana Brasileira, p. 2934, nov. 2008. Disponível em: <http://www.ppge.ufrgs.br/akb>. Acesso em: 8 ago. 2009.
HOSHI, TAKEO; KASHYAP, ANIL. The Japanese Banking Crisis: Where did it come from and how will it end? NBER Working Paper $n^{\circ}$. 7250. 1999. (Cambridge, Massachusetts: National Bureau of Economic Research).

HOSHI, TAKEO; KASHYAP, ANIL., eds. Corporate financing and governance in Japan. Cambridge, Massachusetts: MIT Press, 2001.

HOSHI, TAKEO; KASHYAP, ANIL. Will the U.S. bank recapitalization succeed? Lessons from Japan. NBER Working Paper $n^{o} .14 .401,2008$

\section{INTERNATIONAL MONETARY} FUND. World Economic Outlook Database. Disponível em: <http:// www.imf.org/external>. Acesso em: 15 jan. 2011.

ITO, TAKATOSHI (2000). The stagnant Japanese economy in the 1990s: The need for financial supervision to restore sustained growth. In: HOSHI, Takeo; PATRICK, Hugh (Eds.). Crises and change in the Japanese financial system. Norwell, Kluwer Academic Publishers, 2000.
ITO, TAKATOSHI, (2003) Retrospective on the bubble period and its relationship to developments in the 1990s. Blackwell Publishing Ltd, 9600 Garsington Road, Oxford, OX4 2DQ,

UK and 350 Main Street, Malden, MA 02148, USA.

ITO, TAKATOSHI; MISHKIN, S. FREDERIC. Two decades of Japanese Monetary Policy and the deflation problem. 2004. Working Paper 10878 NATIONAL BUREAU OF ECONOMIC RESEARCH 1050. Massachusetts Avenue Cambridge, MA 02138 October 2004. Disponível em: <http://www.nber.org/papers/ w10878>. Acesso em: 28 fev. 2011.

JINNO, NAOHIKO; KANEKO, MASARU. Stopping Fiscal Collapse. (Tokyo: Iwanami-shoten), 2000.

KALRA, SANJAY. Fiscal Policy: An Evaluation of Its Effectiveness, in Japan's Lost Decade: Policies for Economic Revival. Ed. by Tim Callen and Jonathan Ostry (Washington: International Monetary Fund), 2003.

KANAYA, A.; WOO, D. The Japanese banking crisis of the 1990s: Sources and lessons. International Monetary Fund, Monetary and Exchange Affairs Department, 2000. 
KANG, KENNETH. The resolution and collection corporation and the market for distressed debt in Japan. In: Japan's Lost Decade. Ed. by Tim Callen and Jonathan Ostry (Washington: International Monetary Fund), 2003.

KANG, K.; SYED, M.; TOKUOKA, M., (2009a). Revisiting Japan's Lost Decade. In: Asia and Pacific Regional Economic Outlook, International Monetary Fund, Washington DC.

KANG, K.; SYED, M.; TOKUOKA, M., (2009b). Lost Decade in Translation: What Japan's banking crisis could portend about the U.S. Recovery. IMF Working Paper, forthcoming.

KATZ, R. Lessons for US from Japan's banking crisis. The Oriental Economist. 2009. Disponível em: <http://www. orientaleconomist.com/alert. html>. Acesso em: 5 dez. 2009.

KEYNES, JOHN M. The General Theory of Employment, Interest and Money. London: Macmillan, 1936.

KINDLEBERGER, C. Bubbles. In: EATWELL, J.; MILGATE, M. (Org.). The New Palgrave Dictionary of Money and Finance, 1992.

$\mathrm{KOO}, \mathrm{R}$. The holy grail of macroeconomics: Lessons from Japan's great recession. John Wiley and Sons, 2009.
KREGEL, JAN. Why don't the bailouts work? Design of a new financial system versus a return to normalcy. Cambridge Journal of Economics, 2009, n. 33, p. 653663, 2009. doi:10.1093/cje/bep036.

KRUGMAN, P. It's Baaack! Japan's slump and the return of the liquidity trap. Brookings Papers on Economic Activity, vol. 1998, n.2, p. 137-205, 1998.[http://www.jstor. org/stable/i343502]

KRUGMAN, P.. Thinking about the liquidity trap. Journal of the Japanese and International Economics, 14, p. 221-37, Dec. 2000a.

KRUGMAN, P., 2000b. How complicated does the model have to be? Oxford Review of Economic Policy, vol. 16, n. 4, p. 33-42, 200b.

KUTTNER, KENNETH N.; POSEN, ADAM S. The great recession: Lessons for macroeconomic policy from Japan. Brookings Papers on Economic Activity, n. 2, p. 93 185, 2001.

\section{LEVI, M. L. O sistema de} financiamento das empresas japonesas: A estrutura montada no pós-guerra e os impactos da liberalização financeira da década de 80. Dissertação (Mestrado em Economia) - Instituto de Economia, 140p. Universidade Estadual de Campinas, Campinas: UNICAMP, 1996.

MATSUURA, KATSUMI; HORI, MASAHIRO. Special Credit Guarantee and Restructuring of Small Firms. Cabinet Office, ESRI. Discussion Paper Series n. 50 Tokyo: Cabinet Office, 2003.
MCKINNON, R.; OHNO K. Dollar and yen: Resolving economic conflict between the United States and Japan. Cambridge, Mass.: The MIT Press, 1997.

JAPAN. MINISTRY OF FINANCE. CUSTOMS AND TARIFF BUREAU. Disponível em: < http://www.customs.go.jp >. Acesso em: 4 maio 2009.

MINSKY, H. P. Stabilizing an unstable economy. New Haven: Yale University Press, 1986.

MORJON, B.; OPHÈLE, R.; VINDON, E.; WEBER PIERRE, F. The macroeconomic impact of banking crises. Focus n. 2-5, Dec. 2008. Banque de France.

MOTONISHI, TAIZO;

YOSHIKAWA, Hiroshi. Causes of the long stagnation of Japan during the 1990s: financial or real? Journal of the Japanese and International Economies, vol. 13, p. 181-200, Sept. 1999.

MUHLEISEN, MARTIN. Too much of a good thing? The effectiveness of fiscal stimulus. In: Post-Bubble blues: How Japan responded to asset price collapse. Ed. by Tamim Bayoumi and Charles Collyns. Washington: International Monetary Fund, 2000.

NAKASO, HIROSHI. The financial crisis in Japan during the 1990s: how the Bank of Japan responded and the lessons learnt. BIS Paper n. 6. Basel: Bank for International Settlements, 2001.
ORGANIZATION FOR ECONOMIC CO-OPERATION AND DEVELOPMENT.Disponível em: <http://stats.oecd.org/Index. aspx?DataSetCode>. Acesso em: 28 fev. 2011.

OHASHI, KAZUNARI; SINGH, MANMOHAN. Japan's distressed debt market. IMF Working Paper 04/86. Washington: International Monetary Fund, 2004.

OREIRO. J. L. Bolhas, incerteza e fragilidade financeira: uma abordagem pós-keynesiana. 2001. Disponível em: <http:// www.joseluisoreiro.ecn.br/ artacademicos.asp $>$. Acesso em: 4 set. 2009.

PEEK, J. The Japanese banking crisis: it's not over until the fat lady sings. International Workshop on the Beginning of the New Growth Economic and Social Research Institute, Gabinet Office. Tokyo, Japan, 2004.

POSEN, A. Restoring Japan's economic growth. Policy Analyses in International Economics. Institute for International Economics, 1998.

SADAHIRO, AKIRA. Macro economic analysis in Japan's post-war period. Tokyo:

Toyokeizaishinposha, 2005.

SPILIMBERGO, ANTONIO; SYMANSKY, STEVE; BLANCHARD, OLIVIER; COTTARELLI, CARLO. Fiscal policy for the crisis. IMF Staff Position Note 08/0. Washington: International Monetary Fund, 2008. 
SOMEL, CEM. Finance for growth: lessons from Japan. Unctad, n. 44, July, 1992.

STANDARD e POOR'S. Japan's lost decade offers lessons for current global turmoil. Ratings Direct, December 7, 2008.

\section{TONOOKA, K. EDUARDO.}

A década perdida da economia japonesa. Política Externa, São Paulo, vol. 12, n. 4, p. 35-41, mar./abr. 2004

TORRES Fo, E. T. A economia política do Japão: Reestruturação econômica e seus impactos sobre as relaçôes nipo-brasileiras (1973-1990). Tese (Doutorado em Economia) - Instituto de Economia, 437p. Universidade Federal do Rio de Janeiro. Rio de Janeiro: UFRJ, 1992.

TORRES Fo, E. T. A crise da economia japonesa nos anos 90: Impactos da bolha especulativa. Revista de Economia Politica, v. 17, n. 1 (65), jan./mar. 1997.

\section{TORRES Fo, E. T. Japão:}

características estruturais da crise econômica atual. Rio de Janeiro, Mimeo., 2000.

\section{VATTIPALL, KASHYAP}

Banking crisis in Japan. General

Economics and Teaching. 2004. Disponível em: <http://ideas. repec.org/p/wpa/wuwpgt/0411001. html>. Acesso em: 28 fev. 2011.
WERNER, RICHARD A. Why has fiscal policy disappointed in Japan?

- Revisiting the pré-keynesian view on the ineffectiveness of fiscal policy. Sophia University, Tokyo and Southampton UK, 2004. E51, E62,H30,H60,O42. janeiro 2004.

\section{ZENDRON, PATRÍCIA.}

Instituiçóes bancárias, concessão de crédito e preferência pela liquidez: Três ensaios na perspectiva póskeynesiana. Tese (Doutorado em Economia) - Instituto de Economia, 167p. Universidade Federal do Rio de Janeiro. Rio de Janeiro: UFRJ, 2006.

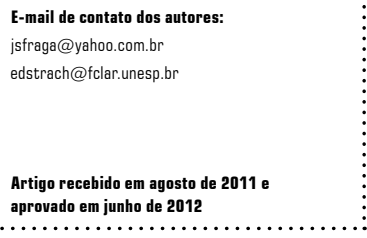


